\title{
EFFECTS OF IMMOBILIZATION IN Ba-ALGINATE ON NITRILE-DEPENDENT OXYGEN UPTAKE RATES OF CANDIDA GUILLIERMONDII
}

\author{
João Carlos Teixeira Dias; Rachel Passos Rezende; Valter Roberto Linardi* \\ Departamento de Microbiologia, Instituto de Ciências Biológicas, Universidade Federal de Minas Gerais, \\ Belo Horizonte, MG, Brasil
}

Submitted: September 27, 2000; Returned to authors for corrections: April 10, 2001; Approved: September 03, 2001

\begin{abstract}
Yeast cells immobilized by entrapment in Ba-alginate gel were investigated for growth pattern and respiratory activity. The oxygen uptake rates (OUR) of cells entrapped in gels with $4 \%$ alginate were 5.2 and $23 \%$ lower than the OUR of $2 \%$ alginate and free cells, respectively. The mass-transfer resistance offered by the matrix and growth of the entrapped cells determine a gradient of nutrients throughout the gel which is responsible for both a lower specific growth rate of immobilized cells with respect to that of free ones, and a heterogeneous biomass distribution, with progressively increasing cellular density from the inside to the outside of the matrix. Gel-matrix polymer concentration affected the maximum oxygen uptake of immobilized growing yeast cells.
\end{abstract}

Key words: Nitriles, Candida guilliermondii, Ba-alginate, respiration

\section{INTRODUCTION}

Industrial use of nitrile may result in discharge of synthetic nitriles into marine, freshwater and soil environments. Increasing accumulation of such compounds in these ecosystems may cause deleterious effects since most of them are highly toxic, mutagenic and carcinogenic (7).

In the practical utilization of living cells entrapped in alginate gel, diffusion of essential nutrients, oxygen transfer, physical and chemical properties of the gel and immobilization procedure are the important factors affecting microbial metabolism and the efficiency of the system. Although immobilized cells have received a lot of attention (2), it is not possible to make a general statement about the behavior of microorganisms in alginate. Literature results are not uniform, but vary according to the type of microorganism, of immobilizing matrix and of productive system.

In the present study Candida guilliermondii UFMG-Y65 cells immobilized by encapsulated in Ba-alginate, were investigated for pattern of growth and the attainment of a spatially organized micro-environment which leads to the formation of a biofilm that controls cell respiratory activity.
Freely suspended cells growing under the same culture conditions were also studied in parallel. We also investigated factors affecting the maximum oxygen uptake of immobilized growing yeast cells such as gel-matrix polymer concentration and length of the period of incubation in $\mathrm{BaCl}_{2}$ solution.

\section{MATERIALS AND METHODS}

\section{Organism}

The yeast was isolated from the gold extraction circuit liquid and identified as Candida guilliermondii UFMG-Y65 (4). The strain was maintained on GYMP agar slant medium ( $2 \%$ glucose, $0.5 \%$ yeast extract, $1 \%$ malt extract, $0.2 \% \mathrm{NaH}_{2} \mathrm{PO}_{4}$, and $2 \%$ agar) under a mineral oil layer and stored at $4^{\circ} \mathrm{C}$ or in liquid nitrogen.

\section{Cell mass production}

C. guilliermondii UFMG-Y 65 was inoculated into $250 \mathrm{ml}$ Erlermeyer flasks containing $50 \mathrm{ml}$ of Yeast Carbon Base (YCB, Difco, Detroit, Mi, USA) with $6 \%$ acetonitrile as the sole nitrogen source, and incubated under shaking at $120 \mathrm{rpm}$ for 120 hours at $25^{\circ} \mathrm{C}$.

\footnotetext{
* Corresponding author. Mailing address: Departamento de Microbiologia, ICB/UFMG, Caixa Postal 486, 31270-901, Belo Horizonte, MG, Brasil. Email: linardiv@mono.icb.ufmg.br
} 


\section{Yeast cells encapsulated by Ba-alginate}

2 or $4 \%$ Alginate $(\mathrm{w} / \mathrm{v})$ was dissolved in boiling water and autoclaved at $121^{\circ} \mathrm{C}$ for $15 \mathrm{~min}$. Six $\mathrm{ml}$ of yeast cell suspension $\left(10^{9} / \mathrm{ml}\right)$ was added to $18 \mathrm{ml}$ sterilized alginate solution and mixed by stirring with a magnetic stirrer. This mixture was extruded drop by drop through hypodermic needles into a cold $0.1 \mathrm{M} \mathrm{BaCl}_{2}$ solution. Gel beads approximately $2 \mathrm{~mm}$ in diameter were obtained. The beads were solidified by resuspending into a fresh $\mathrm{BaCl}_{2}$ solution for $24 \mathrm{~h}$ with gentle shaking at $5^{\circ} \mathrm{C}$. Finally the beads were washed with distilled water and used for experimentation. All experimental steps were performed under aseptic conditions (3).

\section{Culture conditions}

$250 \mathrm{ml}$ Erlenmeyer flasks containing $40 \mathrm{ml}$ of minimum medium ( $1 \%$ glucose, $\left.0.1 \% \mathrm{~K}_{2} \mathrm{HPO}_{4} ; 0.02 \% \mathrm{MgSO}_{4} 7 \mathrm{H}_{2} \mathrm{O} ; 0.01 \% \mathrm{NaCl}\right)$ plus containing $1000 \mathrm{mM}$ of: acetonitrile as the sole nitrogen source were inoculated with $10 \mathrm{ml}$ of gel capsules containing $C$. guilliermondii UFMG-Y65 cells. The flasks were incubated with shaking for 120 hours at $25^{\circ} \mathrm{C}$. A parallel experiment with free cells in solution was also carried out.

\section{Determination of cell concentration}

The samples of free cells were centrifuged for 10 minutes at $5000 \mathrm{rpm}$, and washed twice in deionized water. The cells were then resuspended in $1 \mathrm{ml}$ deionized water and dried for 48 hours at $80^{\circ} \mathrm{C}$. The dry weight of gel capsules and cells, was determined as described by Dias et al. (3). One $\mathrm{mL}$ of capsules was washed with $50 \mathrm{~mL}$ of deionized water and dried by the same procedure as described for free cells.

\section{Measurement of oxygen uptake rates (OUR)}

The rates of cell maximum oxygen uptake were measured at $30^{\circ} \mathrm{C}$ using an Yellow Springs Instrument Co. oxygraph, model 53. The samples with free and immobilized cells were added to $100 \mathrm{mM}$ nitrile or amide solutions, in $3 \mathrm{ml}$ final volume, previously saturated with oxygen. Oxygen consumption was measured immediately after cell immobilization and during the stage of gel bead formation.

\section{Electron microscopy}

Gel beads containing yeast cells were observed by electron microscopy. The capsules containing yeast cells were fixed using a $2.5 \%$ glutaraldeide solution (SIGMA) in $0.1 \mathrm{M}$ phosphate buffer $\mathrm{pH} 7.3$, for 5 hours at $5^{\circ} \mathrm{C}$. After fixation, the samples were washed twice in ice-cold phosphate $(0.1 \mathrm{M}, \mathrm{pH} 7.3)$ for 10 minutes. The material was dehydrated in an ethanol gradient $(50,60,70$, $80,90,95$ and $100 \%$ ), being left for 10 minutes in each solution. The dehydration was repeated twice in $100 \%$ alcohol. The samples were dried adding $0.5 \mathrm{ml}$ hexamethyldisilazane to the material for 30 seconds and the process was repeated twice. The samples were sputter coated and observed under a Zeiss scanning electron microscope (model DSM - 906) at $20 \mathrm{kV}$.
All experiments were repeated three times and the mean values obtained are reported. Data were subjected to analysis of variance. When the main effects were significant $(P<0.005)$ differences between means were evaluated by the Duncan multiple range test.

\section{RESULTS AND DISCUSSION}

Fig. 1 clearly shows the yeast growth in the peripheral regions of the gel, with the formation of small colonies after 72 hours of incubation with shaking. This behavior was observed by several authors $(10,12,13)$, and is due to better nutrient availability, mainly oxygen, in this area. Thus, in the central parts of the beads, the development of colonies was not as robust as found near the surface of the capsule. The reduction of the diffusion coefficient of different substances towards the interior of the gel capsules was studied by some investigators $(5,9,11)$, who observed that the phenomenon is enhanced by the polymer concentration limiting the substrate and product diffusion.

C. guilliermondii UFMG-Y65 grown in acetonitrile showed high oxygen consumption compared to cells grown in the presence of other nitriles (Table 1). According to Nawaz et al.

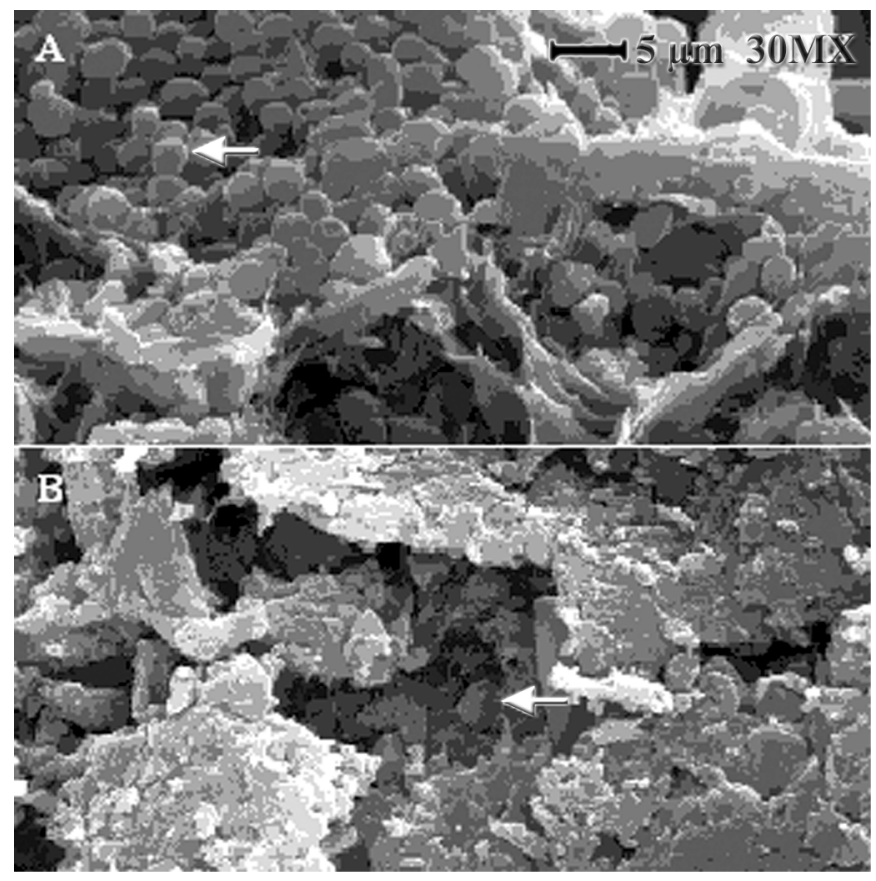

Figure 1. Scanning electron micrograph of immobilized $C$. guilliermondii UFMG-Y65 cells growing in $1000 \mathrm{mM}$ acetonitrile for $72 \mathrm{~h}$. Transverse cut of a gel capsule containing $4 \%$ alginate, cross linked in a $0.1 \mathrm{M} \mathrm{BaCl}_{2}$ solution for 24 hours. Detail of the presence of colonies unequally distributed among the outlying area (A) and the center of the capsule (B) after 72 hours of grow. 
Table 1. Maximum specific oxidation rates (OUR) of compounds (nitriles and amide) by free and immobilized of $C$. guilliermondii UFMG-Y65 cells in phosphate buffer, $\mathrm{pH} 7$, at $30^{\circ} \mathrm{C}$.

\begin{tabular}{|c|c|c|}
\hline \multirow{2}{*}{$\frac{\text { Substrate }}{\text { Nitriles }}$} & \multicolumn{2}{|c|}{$\begin{array}{c}\text { OUR }_{\max } \\
(\text { nmol O} \\
\text { mg }\end{array}$} \\
\hline & Free & Immobilized \\
\hline Acetonitrile & $12.65^{a} \pm 0.35$ & $11.03^{a} \pm 0.57$ \\
\hline Acrylonitrile & $2.57^{d} \pm 0.14$ & $1.45^{e} \pm 0.41$ \\
\hline Adiponitrile & $3.42^{d} \pm 0.26$ & $2.87^{d} \pm 0.33$ \\
\hline Benzonitrile & N.C & $0.76^{f} \pm 0.93$ \\
\hline Butyronitrile & $5.39^{c} \pm 0.18$ & $4.56^{c} \pm 0.24$ \\
\hline 2-cyanopyridine & $3.55^{d} \pm 0.39$ & $2.32^{d} \pm 0.35$ \\
\hline 3-cyanopyridine & $5.32^{c} \pm 0.23$ & $4.85^{c} \pm 0.32$ \\
\hline 4-cyanopyridine & $3.41^{d} \pm 0.37$ & $2.98^{d} \pm 0.55$ \\
\hline Cyclopentanecarbonitrile & N.C & $0.65^{f} \pm 0.47$ \\
\hline Glutaronitrile & $3.54^{d} \pm 0.08$ & $2.75^{d} \pm 0.11$ \\
\hline Isobutyronitrile & $5.67^{c} \pm 0.53$ & $4.45^{c} \pm 0.56$ \\
\hline Methacrylonitrile & $6.89^{c} \pm 0.39$ & $5.39^{c} \pm 0.49$ \\
\hline Propionitrile & $8.73^{b} \pm 0.21$ & $7.21^{b} \pm 0.43$ \\
\hline Succinonitrile & $7.48^{b} \pm 0.34$ & $6.34^{b} \pm 0.21$ \\
\hline Amides & & \\
\hline Acetamide & $7.32^{a} \pm 0.28$ & $6.49^{a} \pm 0.38$ \\
\hline Adipamide & $3.40^{c d} \pm 0.09$ & $2.78^{c} \pm 0.53$ \\
\hline Acrylamide & $3.69^{c d} \pm 0.54$ & $2.04^{c} \pm 0.45$ \\
\hline Benzamide & N.C & $0.71^{d} \pm 0.33$ \\
\hline Isobutyramide & $5.92^{b} \pm 0.43$ & $4.23^{b} \pm 0.47$ \\
\hline Glutaramide & $3.25^{d} \pm 0.35$ & $2.79^{c} \pm 0.26$ \\
\hline Succinamide & $4.36^{c} \pm 0.38$ & $3.58^{b} \pm 0.19$ \\
\hline
\end{tabular}

Immobilization in matrices containing $2 \%$ alginate, cross linked in a $0.1 \mathrm{M} \mathrm{BaCl}_{2}$ solution for 24 hours. Means followed by the same letter are not significantly different $(P<0.005)$ as determined by Duncan's multiple range test; N.C. Not consumed.

(8), oxygen consumption may be considered an approximate measure of enzymatic activity. Oxygen consumption by free cells was not observed in the presence of benzonitrile, benzamide or cyclopentanocarbonitrile, a fact possibly related to the high toxicity of these substances to $C$. guilliermondii UFMG-Y65. Bettmant and Rehm (1) and Goldstein et al. (6) have suggested that immobilization confers greater protection against the toxicants present in the environment. This is probably due to the change in the cell membrane, with a high protein/lipid concentration in the membranes of the immobilized cells. The effect of the immobilization on the maximum specific oxygen uptake rate of $C$. guilliermondii UFMG-Y65 was evaluated in terms of the more important variables in the process of cell immobilization in Ba-alginate gels: $\mathrm{BaCl}_{2}$, polymer concentration and time needed for bead formation.

The oxygen consumption rates of free and immobilized cells were found to be linear during the first 25 minutes (Fig. 2). The assays with immobilized cells presented yielded slightly higher

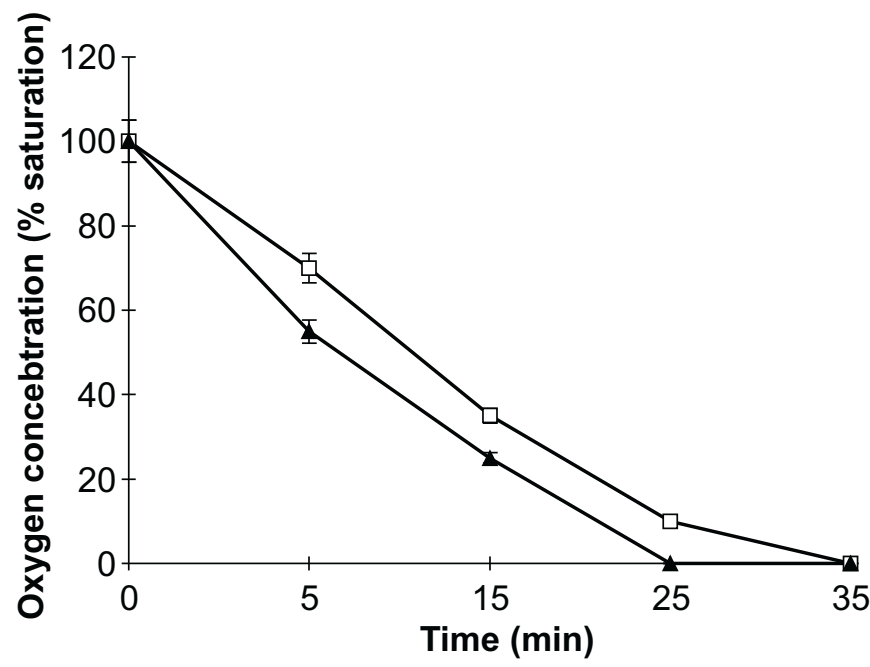

Figure 2. Oxygen consumption of $C$. guilliermondii UFMGY 65 free $(\sigma)$ and immobilized $(||)$ cells in phosphate buffer, $\mathrm{pH}$ 7.0 , at $30^{\circ} \mathrm{C}$, in the presence of $100 \mathrm{mM}$ acetonitrile. Immobilization in $2 \%$ alginate, cross linked in a $0.1 \mathrm{M} \mathrm{BaCl}_{2}$ solution for 24 hours.

compared with free cells, which also shows linear oxygen consumption rates indicating a limitation in the oxygen supply in addition to lower initial rates of microbial oxygen uptake. Scott et al. (11) obtained similar results with Streptomyces clavuligerus cells immobilized in K-carragenan gels. The authors suggested that the rate of external oxygen diffusion from the medium to the capsule, together with the intracapsular diffusion rate, cannot be so high, in order to supply the cells with a sufficient oxygen concentration to allow a maximum rate of cellular oxygen uptake.

Alginate concentrations were varied to evaluate the effect of the different gel bead formation processes on cell oxygen uptake (Table 2). In spite of the restricted number of points, it was observed that maximum oxygen uptake rate of $C$. guilliermondii UFMG-Y65 cells was reduced as the alginate content increased. The OUR of cells entrapped in gels with $4 \%$ alginate were 5.2 and $23 \%$ lower than the OUR of $2 \%$ alginate and free cells, respectively (Table 2). These reductions were probably due to problems of oxygen diffusion and to deleterious effect of the immobilization process. In general, it has been found that oxygen supply in alginate decreases with increased cell loading, bead diameter, and polymer concentration. The differences in oxygen permeability between beds formed with solution containing concentrations of 0.1 and $1 \mathrm{M}$ of the cross linked agent (barium) and 10 min and 24 hours times of gel bead formation were not statistically significant. A $42 \%$ reduction of oxygen consumption rate was observed for free cells in aqueous solution of $1.0 \mathrm{M} \mathrm{BaCl}_{2}$ compared to cells suspended in distilled water under the same conditions (data 
not shown). Similar results were reported by Scott et al. (11). This reduction can also be due to a decrease in the level of available oxygen for cells in solution containing barium chloride because oxygen solubility in $1.0 \mathrm{M} \mathrm{KCl}$ solutions is $74 \%$ of that obtained in distilled water (11). The present data show that free and immobilized yeast cells present different rates of consumption with respect to nitriles and amides. Gelmatrix polymer concentration affected the maximum oxygen uptake of growing immobilized yeast cells.

Table 2. Specific oxygen uptake rates of. free and immobilized of C. guilliermondii UFMG-Y65 cells, in phosphate buffer, $\mathrm{pH}$ 7.0 at $30^{\circ} \mathrm{C}$, in the presence of $100 \mathrm{mM}$ acetonitrile, under different conditions.

\begin{tabular}{cccc}
\hline Test & $\begin{array}{c}\text { Alginate } \\
\text { Concentration } \\
(\%)\end{array}$ & $\begin{array}{c}\text { Conditions of } \\
\text { gel bead } \\
\text { formation }\end{array}$ & $\left.\begin{array}{c}\mathrm{OUR}_{\max }(\mathrm{nmol} \mathrm{O} 2 . \\
\mathrm{mg}^{-1} \text { dry mass. min }\end{array}\right)$ \\
\hline 1 & 2 & $\begin{array}{c}\mathrm{C}_{\mathrm{BaCl}}=1.0 \mathrm{M} \\
\mathrm{tg}=10 \mathrm{~min}\end{array}$ & $10.28^{c b} \pm 0.25$ \\
2 & 2 & $\begin{array}{c}\mathrm{C} \mathrm{BaCl}=0.1 \mathrm{M} \\
\mathrm{tg}=24 \text { hours }\end{array}$ & $11.03^{b} \pm 0.43$ \\
3 & 4 & $\begin{array}{c}\mathrm{C}_{\mathrm{BaCl}}=1.0 \mathrm{M} \\
\mathrm{tg}=10 \mathrm{~min}\end{array}$ & $9.74^{c} \pm 0.33$ \\
4 & Free cells & - & $12.65^{a} \pm 0.35$ \\
\hline
\end{tabular}

Means followed by the same letter are not significantly different $(P<0.005)$ as determined by Duncan's multiple range test; $\mathrm{C}_{\mathrm{BaCl}}$ - Concentration of $\mathrm{BaCl}_{2}$ solution; $\mathrm{tg}=-$ Time of gel bead formation.

\section{ACKNOWLEDGMENTS}

This study was supported by Conselho Nacional de Desenvolvimento Científico e Tecnológico (CNPq) (Proc. 523158/96) and Fundação de Apoio à Pesquisa do Estado de Minas Gerais (FAPEMIG) (CBS 1001/97).

\section{RESUMO}

\section{Efeitos da imobilização em Ba-alginato na taxa de remoção de oxigênio nitrila-dependente pelas células de Candida guilliermondii}

Foram estudados os efeitos da imobilização no crescimento e na atividade respiratória das células de Candida guilliermondii UFMG-Y65 imobilizadas por encapsulamento, utilizando-se gel de Ba-alginato. As taxas máximas de utilização de oxigênio apresentadas pelas células imobilizadas em matriz contendo $4 \%$ de alginato foram 5,2 e $23 \%$ inferiores às taxas apresentadas pelas células imobilizadas em $2 \%$ de alginato e livres, respectivamente A resistência à transferência de massa oferecida pela matriz e o crescimento das células foram responsáveis pela baixa taxa de crescimento. Como conseqüência, observou-se uma distribuição heterogênea da biomassa, com aumento da densidade celular progressivamente do interior para regiões periféricas da matriz. A concentração do polímero afetou a taxa de utilização máxima de oxigênio pelas células da levedura imobilizada.

Palavras-chaves: Nitrilas, Candida guilliermondii, Ba-alginato, respiração

\section{REFERENCES}

1. Bettmann, H.; Rehm, H.J. Degradation of phenol by polymer entrapped microorganisms. Appl. Microbiol. Biotechnol., 20:285290,1984 .

2. Cassidy, M.B.; Lee. H.; Trevors, J.T. Environmental applications of immobilized microbial cells: a review. J. Industrial Microbiol., 16:79101, 1996.

3. Dias, J.C.T.; Rezende, R.P.; Linardi, V.R. Biodegradation of acetonitrile by cells of Candida guilliermondii UFMG-Y65 immobilized in alginate, k-carrageenan and citric pectin. Brazilian J. Microbiol., 31:61-66, 2000a

4. Dias, J.C.T.; Rezende, R.P.; Rosa C.A.; Lachance, M.A.; Linardi, V.R. Enzymatic degradation of nitriles by a Candida guilliermondii UFMG-Y65. Can. J. Microbiol., 46:525-531, 2000 b.

5. Furui, M.; Yamashita, K. Diffusion coefficients of solutes in immobilized cell catalysts. Journal of Fermentation Technology, 63:89-104, 1985

6. Goldstein, R.M.; Mallory, L.M.; Alexander, M. Reasons for possible failure of inoculation to enhance biodegradation. Appl. Environ. Microbiol., 50:977-983, 1985

7. Nawaz, M.S.; Chapatwala, K.D.; Wolfram, J.H. Degradation of acetonitrile by Pseudomonas putida. Appl. Environ. Microbiol., 55:865-875, 1989

8. Nawaz, M.S.; Davis J.W.;Wolfram, J.H.; Chapatwala, K.D Degradation of organic cyanides by Pseudomonas aeruginosa. Appl. Biochem. Biotechnol., 28/29:865-875, 1991.

9. Nguyen, A.L.; Luong, J.H.T. Diffusion in carrageenan gel beads Biotechnol. Bioeng., 28:47-55, 1986.

10. Osuga, J.; Mori, A.; Kato, J. Acid production by immobilized Acetobacter aceti cells entrapped in a k-carragenan gel. J. Ferment. Technol., 62:345-348, 1984

11. Scott, R.I.; Wills, S.J.; Bucke, C. Oxygen uptake by k-carrageenan entrapped Streptomyces clavuligerus. Enz. Microbiol. Technol., 10:258-263, 1989.

12. Sun, Y.; Furusaki, S. Continuous production of acetic acid using immobilized Acetobacter aceti in a three-phase fluidized bed bioreator. J. Ferment. Bioeng., 69:234-237, 1990.

13. Wada, M.; Kato, J.; Chibata, I. Electron microscopic observation of immobilized growing yeast cells. J. Ferment. Technol., 58:78-85, 1980 . 